\title{
RECEIVABLES MANAGEMENT PRACTICES IN SMALL SCALE ENTERPRISES
}

\author{
${ }^{1}$ Dr. Ranganatham G
}

\begin{abstract}
This paper reports the findings of an empirical investigation into the trade credit management practices in small scale enterprises of Anantapur District of Andhra Pradesh. The study involved interviews with ownermanagers in 95 SSEs which comprises of six divergent industrial groups. The findings shows that although short-term financial management practices improve as firms grow, there is a scope for the owner-managers of small businesses to strengthen their trade credit management in order to reduce costs and enhance business performance. Moreover, they have to consider other financial options also.
\end{abstract}

Key Words: Trade credit, Receivables Management, Small Scale Enterprises.

\section{Introduction}

Small and Medium Scale Enterprises (SSEs), irrespective of how they are defined, constitute the vast majority of all enterprises. Such firms, the majority of which are family controlled, make a major contribution to private sector output and employment, and this contribution appears to be increasing over time. The rate of new enterprise formation has increased in recent years. This inturn has sustained growth to a position where they are a major international force (Storey, 1994). The problems, both internal and external, facing small businesses have been the subject of increasing interest. Since the Bolton Report in 1971, there have been a number of surveys and studies of the growth constraints experienced by smaller firms (for example, Soufani 2002, ACOST 1990, Aston Business School 1991, Cambridge Small Business Research Centre (CSBRC) 1992).
The CSBRC (1992) survey concluded that the two most important constraints for all firms relate to matters of finance. Due to diverse financial as well as non-financial and behavioural factors (Poutziouris et al., 1998) small businesses rely more heavily on short-term funding, and this makes them more sensitive to macro-economic changes (Michaelas et al., 1998). Under such circumstances, businesses have to strive for more efficient working capital management. Especially the management of accounts receivable and payable, which make up the largest proportion of working capital needs in small firms.

This paper examines the accounts receivable and accounts payable management practices of Small Scale Enterprises (SSEs). The paper explores how the adoption of the trade credit management practices are followed by selected firms. It is hoped that the results of the research will assist policy

1 Dr. Ranganatham G,

Professor, Dept of Management Studies, Acharya Institute of Management and Sciences,

Peenya, Bangalore -560058. The author can be reached at gangineni.ranganath@gmail.com 
makers, educators and enterprise support agencies (including financiers) to identify the requirements of, and specific problems faced by, SSEs in the select region.

\section{Review of Literature}

The Bolton Committee was critical of several aspects of the financial management of small firms. If reported that information channels were so inefficient, that management frequently learnt of an impending crisis only when the annual accounts appeared, or following an urgent call from the bank manager. In fact, a study conducted by the chartered Institute of Management Accountants in the UK (CIMA, 1994) revealed that 20 per cent of businesses (most of which were smaller firms) failed due to bad debts or poor credit management.

Wilson (1996) shows that those firms with late payment problems were typically reliant on short-term finance and were generally poorer in terms of credit management practice. Similarly, Singleton and Wilson (1998), argue that although late payment is a concern for all small firms, some of them manage it better than others. They find that firms with formal credit management procedures are better in managing late debt. These businesses tend to use longer term finance compared to businesses that have bigger late payment problems and use various forms of short term finance to fund working capital needs (Singleton and Wilson, 1998).

Ashim Kumar Das and Nikhil Bhusan Dey (2004) have conducted a study to analyze practical methods for improving receivable management in small business. For this study, quantitative information obtained from a survey conducted on small business in and around Silchar town of Cachar District of Assam in the year 2002-2003. This study reveals that (a) SMEs followed a liberal credit policy.
It leads to an increase in sales and also leads to an increase in account receivables. (b) The wide gap between the theory and practice of book-keeping and financial management is probably more in small businesses.

Mallikarjunappa (1991) conducted a case study on inventory and receivables position of small scale units in Mangalore taluk. This study was to compare the norms prescribed by the RBI for working capital finance with the actual inventory and receivable position of 10 selected small scale units. For this study comparative analysis statements were used for analyzing the data. The author finally concluded that all the selected small scale units had much lower inventory and receivables level than the prescribed norms. The study revealed that commercial banks have not followed Tan don committee recommendations in extending working capital loans.

\section{Data Collection and Methodology}

\section{Data Collection}

This study examines the management of trade credit practices of SSEs and to provide practical information to policy-makers, financiers, academicians and most importantly business owner/ managers. The study involved interviews with owner/ managers in 95 SSEs operating in the Anantapur District of six different industrial estates, by using a pre-tested schedule.

\section{Sample}

The study is based on the data collected from 95 working small scale enterprises consisting of six divergent industrial groups, selected at random, in six industrial estates of Anantapur district of Andhra Pradesh. Care was taken to select approximately 50 per cent of the small scale enterprises from each industrial category. The number of units selected industry-wise is shown in table 1. 
Table 1: Industry-Wise Classification of Sample Small Scale Enterprises

\begin{tabular}{|l|c|c|c|}
\hline Industry Type & No. of Working Units in Universe & $\begin{array}{c}\text { Sample } \\
\text { (No. of Units) }\end{array}$ & Percentage \\
\hline Engineering & 64 & 32 & 50.00 \\
\hline Mineral & 50 & 25 & 50.00 \\
\hline Agro-Based & 18 & 10 & 55.55 \\
\hline Plastic & 16 & 09 & 56.25 \\
\hline Chemical & 07 & 04 & 57.14 \\
\hline Miscellaneous & 28 & 15 & 53.57 \\
\hline Total & 183 & 95 & 51.91 \\
\hline
\end{tabular}

Source: Records of Andhra Pradesh Industrial Infrastructure Corporation Limited, Industrial Estates of Anantapur and Hindupur.

\section{Data Analysis and Interpretation}

\section{Method of Sales}

Table 2 shows the sales practices in select small scale enterprises. The possible sales practices are 'cash sales only', 'credit sales only' and 'both cash and credit sales'. Only 14.74 per cent of the select small scale enterprises sell only for cash, 23.16 per cent of the select small scale enterprises sell only on credit, and the remaining 62.10 per cent of the select small scale enterprises sell both for cash and on credit. Industry-wise analysis shows that:

Table: 2 Sales Practices in the Selected Small Scale Enterprises

\begin{tabular}{|c|c|c|c|c|c|c|c|c|}
\hline \multirow{2}{*}{ SI. No. } & \multirow{2}{*}{ Sales Practices } & \multicolumn{6}{|c|}{ Industry Type } & \multirow{2}{*}{ Total } \\
\hline & & Eng & Min & Agro & Pla & Che & Mis & \\
\hline 1 & Cash sales only & $\begin{array}{l}0 \\
-\end{array}$ & $\begin{array}{c}05 \\
(20.00)\end{array}$ & $\begin{array}{c}04 \\
(44.45)\end{array}$ & $\begin{array}{c}01 \\
(12.50)\end{array}$ & $\begin{array}{c}03 \\
(75.00)\end{array}$ & $\begin{array}{c}01 \\
(5.88)\end{array}$ & $\begin{array}{c}14 \\
(14.74)\end{array}$ \\
\hline 2 & Credit sales only & $\begin{array}{c}16 \\
(50.00)\end{array}$ & $\begin{array}{c}01 \\
(4.00)\end{array}$ & $\begin{array}{c}02 \\
(22.22)\end{array}$ & $\begin{array}{c}01 \\
(12.50)\end{array}$ & $\begin{array}{l}0 \\
-\end{array}$ & $\begin{array}{c}02 \\
(11.77)\end{array}$ & $\begin{array}{c}22 \\
(23.16)\end{array}$ \\
\hline 3 & $\begin{array}{l}\text { Both cash and } \\
\text { credit sales }\end{array}$ & $\begin{array}{c}16 \\
(50.00)\end{array}$ & $\begin{array}{c}19 \\
(76.00)\end{array}$ & $\begin{array}{c}03 \\
(33.33)\end{array}$ & $\begin{array}{c}06 \\
(75.00)\end{array}$ & $\begin{array}{c}01 \\
(25.00)\end{array}$ & $\begin{array}{c}14 \\
(82.35)\end{array}$ & $\begin{array}{c}59 \\
(62.10)\end{array}$ \\
\hline --- & Total & $\begin{array}{c}32 \\
(100)\end{array}$ & $\begin{array}{c}25 \\
(100)\end{array}$ & $\begin{array}{c}09 \\
(100)\end{array}$ & $\begin{array}{c}08 \\
(100)\end{array}$ & $\begin{array}{c}04 \\
(100)\end{array}$ & $\begin{array}{c}17 \\
(100)\end{array}$ & $\begin{array}{c}95 \\
(100)\end{array}$ \\
\hline
\end{tabular}

Source: Field Survey

Note: Figures in the parentheses are the percentages on the column totals 
- None of the engineering enterprises, 20.00 percent of the mineral-based enterprises, 44.45 percent of the agro based enterprises, 12.50 percent of the plastic enterprises, 75.00 percent of the chemical enterprises, and 5.88 percent of the miscellaneous enterprises follow the practice of selling goods and services only on cash basis.

- One-half of the engineering enterprises, 4.00 percent of the mineral-based enterprises, 22.22 percent of the agro-based enterprises, 12.50 percent of the plastic enterprises, none of the chemical enterprises, and 11.77 percent of the miscellaneous enterprises follow the practice of selling their goods and services on credit basis only.

- One-half of the engineering enterprises, 76.00 percent of the mineral-based enterprises, 33.33 percent of the agro-based enterprises, 75.00 percent of the plastic enterprises, 25.00 percent of the chemical enterprises, and 82.35 percent of the miscellaneous enterprises follow the practice of selling their goods and services both on credit and cash basis.

To conclude, a majority of the select small scale enterprises follow the practice of selling their end products both for cash and on credit. It is also evident that a large number of small scale enterprises adopt credit sales as a motivating variable for effecting sales. Other noteworthy point in the analysis is none of the engineering enterprises follow the practice of selling their goods and services on cash basis only and 50.00 per cent of the engineering enterprises follow the practice of selling goods and services on credit basis only. The reason for this is some of the engineering enterprises surveyed are ancillaries to Wipro (Company). They receive raw materials from 'Wipro' and supply their products to 'Wipro' on credit basis.

\section{Forms of Credit Sales}

The forms of credit sales existing in the selected small scale enterprises are of two types, first one is of debtors or bills receivables, and the other of open account. In case of debtors or bills receivables, credit sales lead to creation of written legal document i.e., bills. In the case of open account form of credit sales, there would be no written document as to the credit sales affected. The open account practiced in the selected small scale enterprises are of two types. In the first case, the party supplying raw material to the small scale enterprises, purchases back the product made out of the raw material. The arrangement is on an ongoing basis. The account settlement period depends upon mutual understanding of the parties concerned. In the second case, two small scale enterprises in the same industrial area established an open account arrangement for all their mutual exchanges. Both the types of methods are mostly seen among the enterprises located in Hindupur Industrial Estate, mostly in engineering enterprises and also in some other industrial enterprises.

Table 3 shows, forms of trade credit provided by the select small scale enterprises. The possible forms of credit sales include 'debtors/bills receivable', 'open account' and 'both debtors/bills receivables and open account'. Forty per cent of the select small scale enterprises provide credit in the form of debtors/ receivables, 18.95 per cent of the select small scale enterprises provide open account form of credit, and the remaining 26.32 per cent of the select small scale enterprises provide credit both in the form of 'debtors/bills receivables and open account'. Industry-wise analysis shows that: 
Table: 3 Forms of Trade Credit Provided by the Selected Small Scale Enterprises

\begin{tabular}{|c|c|c|c|c|c|c|c|}
\hline \multirow{2}{*}{$\begin{array}{c}\text { Forms of } \\
\text { Credit Sales }\end{array}$} & \multicolumn{6}{|c|}{ Industry Type } & \multirow{2}{*}{ Total } \\
\hline & Eng & Min & Agro & Pla & Che & Mis & \\
\hline Debtors / bills receivables & $\begin{array}{c}13 \\
(40.62)\end{array}$ & $\begin{array}{c}10 \\
(40.00)\end{array}$ & $\begin{array}{c}5 \\
(55.56)\end{array}$ & $\begin{array}{c}4 \\
(50.00)\end{array}$ & $\begin{array}{c}1 \\
(25.00)\end{array}$ & $\begin{array}{c}5 \\
(29.41)\end{array}$ & $\begin{array}{c}38 \\
(40.00)\end{array}$ \\
\hline Open account & $\begin{array}{c}11 \\
(34.38)\end{array}$ & $\begin{array}{c}3 \\
(12.00)\end{array}$ & $\begin{array}{c}1 \\
(11.11)\end{array}$ & $\begin{array}{c}2 \\
(25.00)\end{array}$ & $\begin{array}{l}0 \\
-\end{array}$ & $\begin{array}{c}1 \\
(5.88)\end{array}$ & $\begin{array}{c}18 \\
(18.95)\end{array}$ \\
\hline $\begin{array}{l}\text { Both open \& debtors / bills } \\
\text { receivables }\end{array}$ & $\begin{array}{c}8 \\
(25.00)\end{array}$ & $\begin{array}{c}7 \\
(28.00)\end{array}$ & $\begin{array}{c}2 \\
(22.22)\end{array}$ & $\begin{array}{l}0 \\
-\end{array}$ & $\begin{array}{l}0 \\
-\end{array}$ & $\begin{array}{c}8 \\
(47.06)\end{array}$ & $\begin{array}{c}25 \\
(26.32)\end{array}$ \\
\hline Not applicable & $\begin{array}{l}0 \\
-\end{array}$ & $\begin{array}{c}5 \\
(20.00)\end{array}$ & $\begin{array}{c}1 \\
(11.11)\end{array}$ & $\begin{array}{c}2 \\
(25.00)\end{array}$ & $\begin{array}{c}3 \\
(75.00)\end{array}$ & $\begin{array}{c}3 \\
(17.65)\end{array}$ & $\begin{array}{c}14 \\
(14.73)\end{array}$ \\
\hline Total & $\begin{array}{c}32 \\
(100)\end{array}$ & $\begin{array}{c}25 \\
(100)\end{array}$ & $\begin{array}{c}9 \\
(100)\end{array}$ & $\begin{array}{c}8 \\
(100)\end{array}$ & $\begin{array}{c}4 \\
(100)\end{array}$ & $\begin{array}{c}17 \\
(100)\end{array}$ & $\begin{array}{c}95 \\
(100)\end{array}$ \\
\hline
\end{tabular}

Source: Field Survey

Note: Figures in the parentheses are the percentages on the column totals.

- 40.62 per cent of the engineering enterprises, 40.00 per cent of the mineral-based enterprises, 55.56 per cent of the agro-based enterprises, 50.00 per cent of the plastic enterprises, 25.00 per cent of the chemical enterprises, and 29.41 per cent of the miscellaneous enterprises provide credit in the form of 'debtors/bills receivables'.

- $\quad 34.38$ percent of the engineering enterprises, 12.00 percent of the mineral-based enterprises, 11.11 percent of the agro-based enterprises, 25.00 percent of the plastic enterprises, none of the chemical enterprises, and 5.88 percent of the miscellaneous enterprises provide credit in the form of 'open account'.

- 25.00 percent of the engineering enterprises, 28.00 percent of the mineral-based enterprises, 22.22 percent of the agro-based enterprises, none of the plastic and chemical enterprises, and 47.06 percent of the miscellaneous enterprises provide credit both in the form of 'debtors/bills receivables' and 'open account'.
- For 20.00 per cent of the mineral-based enterprises, 11.11 per cent of the agro-based enterprises, 25.00 per cent of the plastic enterprises, 75.00 per cent of the chemical enterprises, and 17.65 per cent of the miscellaneous enterprises the concept forms of credit is not applicable as they do not provide any credit.

\section{Reasons for Credit Sales}

Reasons necessitating the select small scale enterprises to sell their goods on credit basis are shown in table 4 . The possible reasons as conceived by the researcher are, 'market tradition', 'sales promotion', 'demand from friends', and 'accommodating special customers'. About twenty seven per cent of the select small scale enterprises provide credit because of market tradition, 18.95 per cent of the select small scale enterprises provide credit as a sales promotion measure, 28.42 per cent of the select small scale enterprises provide credit to concede to the demand from friends, and the remaining 10.53 per cent of the select small scale enterprises allow credit to accommodate special customers. Industry-wise analysis shows that: 
Table: 4 Reasons for Making Credit sales in the Selected Small Scale Enterprises

\begin{tabular}{|c|c|c|c|c|c|c|c|}
\hline \multirow{2}{*}{ Reasons } & \multicolumn{6}{|c|}{ Industry Type } & \multirow{2}{*}{ Total } \\
\hline & Eng & Min & Agro & Pla & Che & Mis & \\
\hline Market tradition & $\begin{array}{c}21 \\
(65.63)\end{array}$ & $\begin{array}{l}0 \\
-\end{array}$ & $\begin{array}{c}1 \\
(11.11)\end{array}$ & $\begin{array}{c}4 \\
(50.00)\end{array}$ & $\begin{array}{l}0 \\
-\end{array}$ & $\begin{array}{l}0 \\
-\end{array}$ & $\begin{array}{c}26 \\
(27.37)\end{array}$ \\
\hline Sales promotion & $\begin{array}{c}2 \\
(6.25)\end{array}$ & $\begin{array}{c}7 \\
(68.00)\end{array}$ & $\begin{array}{c}3 \\
(33.33)\end{array}$ & $\begin{array}{c}1 \\
(12.50)\end{array}$ & $\begin{array}{l}0 \\
-\end{array}$ & $\begin{array}{c}5 \\
(29.41)\end{array}$ & $\begin{array}{c}18 \\
(18.95)\end{array}$ \\
\hline Demand from friends & $\begin{array}{c}5 \\
(15.62)\end{array}$ & $\begin{array}{c}11 \\
(44.00)\end{array}$ & $\begin{array}{c}1 \\
(11.11)\end{array}$ & $\begin{array}{c}1 \\
(12.50)\end{array}$ & $\begin{array}{c}1 \\
(25.00)\end{array}$ & $\begin{array}{c}8 \\
(47.06)\end{array}$ & $\begin{array}{c}27 \\
(28.42)\end{array}$ \\
\hline $\begin{array}{l}\text { Accommodating special } \\
\text { customers }\end{array}$ & $\begin{array}{c}4 \\
(12.50)\end{array}$ & $\begin{array}{c}2 \\
(8.00)\end{array}$ & $\begin{array}{c}3 \\
(33.33)\end{array}$ & $\begin{array}{l}0 \\
-\end{array}$ & $\begin{array}{l}0 \\
-\end{array}$ & $\begin{array}{c}1 \\
(5.88)\end{array}$ & $\begin{array}{c}10 \\
(10.53)\end{array}$ \\
\hline Not applicable & $\begin{array}{l}0 \\
-\end{array}$ & $\begin{array}{c}5 \\
(20.00)\end{array}$ & $\begin{array}{c}1 \\
(11.12)\end{array}$ & $\begin{array}{c}2 \\
(25.00)\end{array}$ & $\begin{array}{c}3 \\
(75.00)\end{array}$ & $\begin{array}{c}3 \\
(17.65)\end{array}$ & $\begin{array}{c}14 \\
(14.73)\end{array}$ \\
\hline Total & $\begin{array}{c}32 \\
(100)\end{array}$ & $\begin{array}{c}25 \\
(100)\end{array}$ & $\begin{array}{c}9 \\
(100)\end{array}$ & $\begin{array}{c}8 \\
(100)\end{array}$ & $\begin{array}{c}4 \\
(100)\end{array}$ & $\begin{array}{c}17 \\
(100)\end{array}$ & $\begin{array}{c}95 \\
(100)\end{array}$ \\
\hline
\end{tabular}

Source: Field Survey

Note: Figures in the parentheses are the percentages on the column totals.

- $\quad 65.63$ percent of the engineering enterprises, none of the mineral-based, chemical and miscellaneous enterprises, 11.11 percent of the agro-based enterprises, and 50.00 percent of the plastic enterprises allow credit as it is the 'market tradition'.

- 6.25 per cent of the engineering enterprises, 68.00 per cent of the mineral-based enterprises, 33.33 per cent of the agro-based enterprises, 12.50 per cent of the plastic enterprises, none of the chemical enterprises, and 29.41 per cent of the miscellaneous enterprises treat credit as a 'sales promotion' measure.

- $\quad 15.62$ percent of the engineering enterprises, 44.00 percent of the mineral-based enterprises, 11.11 per cent of the agro-based enterprises, 12.50 percent of the plastic enterprises, 25.00 percent of the chemical enterprises, and 47.06 percent of the miscellaneous enterprises provide credit to concede to the 'request of the friends'.

- 12.50 percent of the engineering enterprises, 8.00 percent of the mineral-based enterprises, 33.33 percent of the agro-based enterprises, none of the plastic and chemical enterprises, and 5.88 percent of the miscellaneous enterprises provide credit to 'accommodate the needs of special customers' if any.

- For rest of the enterprises it is not applicable.

\section{Duration of Credit}

Table 5 presents details of duration of credit extended by the select small scale enterprises. Twenty per cent of the select small scale enterprises provide one week credit, 33.68 per cent of the select small scale enterprises provide credit upto three weeks credit, 23.16 per cent of the select small scale enterprises provide credit up to five weeks, $8.42 \mathrm{per}$ cent of the select small 
scale enterprises provide more than five weeks credit. Industry-wise analysis shows that:

- The practice in 6.25 percent of the engineering enterprises, 24.00 percent of the mineral-based enterprises, 44.45 percent of the agro-based enterprises, 25.00 percent each of the plastic enterprises, none of the chemical enterprises, and in 29.41 percent of the miscellaneous enterprises is to provide credit upto one week.
- The practice in 50.00 percent of the engineering enterprises, 20.00 percent of the mineral-based enterprises, 33.33 percent of the agro-based enterprises, 25.00 percent of the plastic and chemical enterprises, and in 29.41 percent of the miscellaneous enterprises, is to provide credit upto three weeks.

Table: 5 Duration of Credit Extended to Customers in the Selected Small Scale Enterprises

\begin{tabular}{|c|c|c|c|c|c|c|c|}
\hline \multirow{2}{*}{$\begin{array}{c}\text { Duration of } \\
\text { Credit }\end{array}$} & \multicolumn{6}{|c|}{ Industry Type } & \multirow{2}{*}{ Total } \\
\hline & Eng & Min & Agro & Pla & Che & Mis & \\
\hline Up to one week & $\begin{array}{c}2 \\
(6.25)\end{array}$ & $\begin{array}{c}6 \\
(24.00)\end{array}$ & $\begin{array}{c}04 \\
(44.45)\end{array}$ & $\begin{array}{c}02 \\
(25.00)\end{array}$ & $\begin{array}{l}0 \\
-\end{array}$ & $\begin{array}{c}05 \\
(29.41)\end{array}$ & $\begin{array}{c}19 \\
(20.00)\end{array}$ \\
\hline Up to three weeks & $\begin{array}{c}16 \\
(50.00)\end{array}$ & $\begin{array}{c}5 \\
(20.00)\end{array}$ & $\begin{array}{c}03 \\
(33.33)\end{array}$ & $\begin{array}{c}02 \\
(25.00)\end{array}$ & $\begin{array}{c}01 \\
(25.00)\end{array}$ & $\begin{array}{c}05 \\
(29.41)\end{array}$ & $\begin{array}{c}32 \\
(33.68)\end{array}$ \\
\hline Up to five weeks & $\begin{array}{c}9 \\
(28.13)\end{array}$ & $\begin{array}{c}6 \\
(24.00)\end{array}$ & $\begin{array}{l}0 \\
-\end{array}$ & $\begin{array}{c}01 \\
(12.50)\end{array}$ & $\begin{array}{l}0 \\
-\end{array}$ & $\begin{array}{c}06 \\
(35.29)\end{array}$ & $\begin{array}{c}22 \\
(23.16)\end{array}$ \\
\hline More than five weeks & $\begin{array}{c}5 \\
(15.63)\end{array}$ & $\begin{array}{c}3 \\
(12.00)\end{array}$ & $\begin{array}{l}8 \\
-\end{array}$ & $\begin{array}{l}0 \\
-\end{array}$ & $\begin{array}{l}0 \\
-\end{array}$ & $\begin{array}{l}0 \\
-\end{array}$ & $\begin{array}{c}08 \\
(8.42)\end{array}$ \\
\hline Not applicable & $\begin{array}{l}0 \\
-\end{array}$ & $\begin{array}{c}5 \\
(20.00)\end{array}$ & $\begin{array}{c}02 \\
(22.22)\end{array}$ & $\begin{array}{c}03 \\
(37.50)\end{array}$ & $\begin{array}{c}03 \\
(75.00)\end{array}$ & $\begin{array}{c}01 \\
(5.88)\end{array}$ & $\begin{array}{c}14 \\
(14.74)\end{array}$ \\
\hline Total & $\begin{array}{c}32 \\
(100)\end{array}$ & $\begin{array}{c}25 \\
(100)\end{array}$ & $\begin{array}{c}09 \\
(100)\end{array}$ & $\begin{array}{c}08 \\
(100)\end{array}$ & $\begin{array}{c}04 \\
(100)\end{array}$ & $\begin{array}{c}17 \\
(100)\end{array}$ & $\begin{array}{c}95 \\
(100)\end{array}$ \\
\hline
\end{tabular}

Source: Field Survey

Note: Figures in the parentheses are the percentages on the column totals.

- The practice in 28.13 per cent of the engineering enterprises, 24.00 per cent of the mineral-based enterprises, none of the agro based and chemical enterprises, 12.50 percent of the plastic enterprises, and in 35.29 percent of the miscellaneous enterprises is to provide credit upto five weeks.
- In 15.63 percent of the engineering and 12.00 percent of the mineral-based enterprises, the practice is to provide credit for more than five weeks.

The period of time, for which credit is extended would usually be short in SSE sector. The reason is that these enterprises have limited accessibility to liquid funds. 


\section{Evaluation of Credit Worthiness of the Customers}

Before rendering credit sales to the customers, the firms shall evaluate the credit worthiness of the customers. For this purpose, enterprises follow various methods, which are shown in table 6. A perusal of the table indicates that, as many as 55.79 per cent of the respondent enterprises evaluate credit worthiness of the customers, on the basis of 'past experience', 14.74 per cent of the respondent enterprises evaluate the credit worthiness of the customers, on the basis of the opinions collected from the 'friends and relatives', 12.63 per cent of the respondent enterprises evaluate the credit worthiness of the customers, on the basis of 'public enquiry', 9.47 per cent of the respondent enterprises evaluate credit worthiness of the customers, on the basis of the opinions expressed by the 'sales representatives', and 7.37 per cent of the respondent enterprises evaluate credit worthiness of the customers , on the basis of 'bank reference'. Industry-wise analysis shows that:

Table: 6 Methods of Evaluation of Credit Worthiness of the Customers Used by the Selected Small Scale Enterprises

\begin{tabular}{|c|c|c|c|c|c|c|c|}
\hline \multirow{2}{*}{ Methods } & \multicolumn{6}{|c|}{ Industry Type } & \multirow{2}{*}{ Total } \\
\hline & Eng & Min & Agro & Pla & Che & Mis & \\
\hline Past experience & $\begin{array}{c}20 \\
(62.50)\end{array}$ & $\begin{array}{c}12 \\
(48.00)\end{array}$ & $\begin{array}{c}03 \\
(33.33)\end{array}$ & $\begin{array}{c}7 \\
(87.50)\end{array}$ & $\begin{array}{c}1 \\
(25.00)\end{array}$ & $\begin{array}{c}10 \\
(58.82)\end{array}$ & $\begin{array}{c}53 \\
(55.79)\end{array}$ \\
\hline Friends \& relatives & $\begin{array}{c}4 \\
(12.50)\end{array}$ & $\begin{array}{c}3 \\
(12.00)\end{array}$ & $\begin{array}{l}0 \\
-\end{array}$ & $\begin{array}{l}0 \\
-\end{array}$ & $\begin{array}{l}0 \\
-\end{array}$ & $\begin{array}{c}7 \\
(41.18)\end{array}$ & $\begin{array}{c}14 \\
(14.74)\end{array}$ \\
\hline Public enquiry & $\begin{array}{c}3 \\
(9.37)\end{array}$ & $\begin{array}{c}8 \\
(32.00)\end{array}$ & $\begin{array}{l}0 \\
-\end{array}$ & $\begin{array}{c}1 \\
(12.50)\end{array}$ & $\begin{array}{l}0 \\
-\end{array}$ & $\begin{array}{l}0 \\
-\end{array}$ & $\begin{array}{c}12 \\
(12.63)\end{array}$ \\
\hline Sales representatives & $\begin{array}{l}0 \\
-\end{array}$ & $\begin{array}{l}0 \\
-\end{array}$ & $\begin{array}{c}06 \\
(66.67)\end{array}$ & $\begin{array}{l}0 \\
-\end{array}$ & $\begin{array}{c}3 \\
(75.00)\end{array}$ & $\begin{array}{l}0 \\
-\end{array}$ & $\begin{array}{c}9 \\
(9.47)\end{array}$ \\
\hline Bank reference & $\begin{array}{c}5 \\
(15.63)\end{array}$ & $\begin{array}{c}2 \\
(8.00)\end{array}$ & $\begin{array}{l}0 \\
-\end{array}$ & $\begin{array}{l}0 \\
-\end{array}$ & $\begin{array}{l}0 \\
-\end{array}$ & $\begin{array}{l}0 \\
-\end{array}$ & $\begin{array}{c}7 \\
(7.37)\end{array}$ \\
\hline Total & $\begin{array}{c}32 \\
(100)\end{array}$ & $\begin{array}{c}25 \\
(100)\end{array}$ & $\begin{array}{c}9 \\
(100)\end{array}$ & $\begin{array}{c}8 \\
(100)\end{array}$ & $\begin{array}{c}4 \\
(100)\end{array}$ & $\begin{array}{c}17 \\
(100)\end{array}$ & $\begin{array}{c}95 \\
(100)\end{array}$ \\
\hline
\end{tabular}

Source: Field Survey

Note: Figures in the parentheses are the percentages on the column totals.

- 62.50 per cent of the engineering enterprises, 48.00 percent of the mineral-based enterprises, 33.33 percent of the agro-based enterprises, 87.50 percent of the plastic enterprises, 25.00 percent of the chemical enterprises, and 58.82 percent of the miscellaneous enterprises evaluate the credit worthiness of the customers, on the basis of 'past experience'. That is a majority of the engineering, plastic and miscellaneous enterprises evaluate the creditworthiness of the customers on the basis of past experience.

- 12.50 per cent of the engineering enterprises, 12.00 per cent of the mineral-based enterprises; none of the agro-based, plastic and chemical enterprises; and 41.18 per cent of the miscellaneous enterprises evaluate the credit worthiness of the customers, on the basis of the opinions expressed by 'friends and relatives'. Thus a considerable number of miscellaneous enterprises follow this method for evaluating the creditworthiness of the customers. 
- $\quad 9.37$ percent of the engineering enterprises; 32.00 percent of the mineral-based enterprises; 12.50 percent of the plastic enterprises; and none of the agro-based, chemical and miscellaneous enterprises evaluate the credit worthiness of the customers, on the basis of 'public enquiry'. A few engineering, mineralbased and plastic enterprises use this method, whereas agro-based, chemical and miscellaneous enterprises do not use this method for evaluating the creditworthiness of the customers.
- As many as 66.67 per cent of the agro-based and 75.00 per cent of the chemical enterprises evaluate the creditworthiness of the customers, based upon the reports of the sales representatives. Thus, majority of the agrobased and chemical enterprises follow this method. None of the engineering, mineralbased, plastic and miscellaneous enterprises follow this method.

- $\quad 15.63$ per cent of the engineering and 8.00 percent of the mineral-based enterprises follow the method of evaluating creditworthiness of the customers, based upon bank reference. Others do not follow this method.

\section{Evolving Credit Policy}

Table 7 shows the types of credit policies followed by the selected small scale enterprises. As many as 91.58 per cent of the enterprises follow independent credit policy and only 8.42 per cent of the enterprises follow dependent credit policy.

Table: 7 Types of Credit Policies

\begin{tabular}{|c|c|c|c|c|c|c|c|}
\hline \multirow{2}{*}{ Credit Policies } & \multicolumn{6}{|c|}{ Industry Type } & \multirow{2}{*}{ Total } \\
\hline & Eng & Min & Agro & Pla & Che & Mis & \\
\hline Independent credit policy & $\begin{array}{c}29 \\
(90.63)\end{array}$ & $\begin{array}{c}21 \\
(84.00)\end{array}$ & $\begin{array}{c}8 \\
(88.89)\end{array}$ & $\begin{array}{c}9 \\
(100)\end{array}$ & $\begin{array}{c}4 \\
(100.00)\end{array}$ & $\begin{array}{c}17 \\
(100)\end{array}$ & $\begin{array}{c}87 \\
91.58)\end{array}$ \\
\hline Dependent credit policy & $\begin{array}{c}3 \\
(9.37)\end{array}$ & $\begin{array}{c}4 \\
(16.00)\end{array}$ & $\begin{array}{c}1 \\
(11.11)\end{array}$ & $\begin{array}{l}0 \\
-\end{array}$ & $\begin{array}{l}0 \\
-\end{array}$ & $\begin{array}{l}0 \\
-\end{array}$ & $\begin{array}{c}8 \\
(8.42)\end{array}$ \\
\hline Total & $\begin{array}{c}32 \\
(100)\end{array}$ & $\begin{array}{c}25 \\
(100)\end{array}$ & $\begin{array}{c}9 \\
(100)\end{array}$ & $\begin{array}{c}8 \\
(100)\end{array}$ & $\begin{array}{c}4 \\
(100)\end{array}$ & $\begin{array}{c}17 \\
(100)\end{array}$ & $\begin{array}{c}95 \\
(100)\end{array}$ \\
\hline
\end{tabular}

Source: Field Survey

Note: Figures in the parentheses are the percentages on the column totals.

Industry-wise analysis shows that 90.63 percent of the engineering enterprises; 84.00 percent of the mineral-based enterprises; 88.89 percent of the agro-based enterprises; and 100 percent of the plastic, chemical, and miscellaneous enterprises follow an independent credit policy. Hence it can be concluded that a great majority of select small scale enterprises follow an independent credit policy.

\section{Differential Credit Policy}

Eighty per cent of select small scale enterprises do not follow the same credit policy for all customers. Nearly 80.00 per cent of the enterprises use the credit terms to their customers, based on their credit worthiness and past experience with them, attitude towards repayment and nature of business. All these factors influence the credit policy of the enterprises. Remaining 20.00 per cent of select small scale enterprises follow the same credit policy to all the customers. This is shown in the table 8. 
Table: 8 Differential Credit Policies to the Customers

\begin{tabular}{|c|c|c|c|c|c|c|c|}
\hline \multirow{2}{*}{ Same Policy } & \multicolumn{6}{|c|}{ Industry Type } & \multirow{2}{*}{ Total } \\
\hline & Eng & Min & Agro & Pla & Che & Mis & \\
\hline Yes & $\begin{array}{c}5 \\
(15.63)\end{array}$ & $\begin{array}{c}6 \\
(24.00)\end{array}$ & $\begin{array}{c}1 \\
(11.11)\end{array}$ & $\begin{array}{c}4 \\
(50.00)\end{array}$ & $\begin{array}{l}0 \\
-\end{array}$ & $\begin{array}{c}3 \\
(17.65)\end{array}$ & $\begin{array}{c}19 \\
(20.00)\end{array}$ \\
\hline No & $\begin{array}{c}27 \\
(84.38)\end{array}$ & $\begin{array}{c}19 \\
(76.00)\end{array}$ & $\begin{array}{c}8 \\
(88.89)\end{array}$ & $\begin{array}{c}4 \\
(50.00)\end{array}$ & $\begin{array}{c}4 \\
(100)\end{array}$ & $\begin{array}{c}14 \\
(82.35)\end{array}$ & $\begin{array}{c}76 \\
(80.00)\end{array}$ \\
\hline Total & $\begin{array}{c}32 \\
(100)\end{array}$ & $\begin{array}{c}25 \\
(100)\end{array}$ & $\begin{array}{c}09 \\
(100)\end{array}$ & $\begin{array}{c}08 \\
(100)\end{array}$ & $\begin{array}{c}04 \\
(100)\end{array}$ & $\begin{array}{c}17 \\
(100)\end{array}$ & $\begin{array}{c}95 \\
(100)\end{array}$ \\
\hline
\end{tabular}

Source: Field Survey

Note: Figures in the parentheses are the percentages on the column totals.

\section{Changing the Credit Policy}

The credit policy of select small scale enterprises depends on various conditions of business. It may become necessary to change the credit policy. An attempt has been made to find how frequently if at all the policy is changed out. The responses have been processed and shown in table 9 . As many as 75.79 per cent of the select small scale enterprises say that they change the credit policy now and then, 16.84 per cent of the select small scale enterprises say that they change the policy frequently, and 7.37 per cent of select small scale enterprises say they never change the credit policy. Changing the credit policy frequently is not favourable, at the same time never changing the policy is also not advisable. Changing the policy 'now and then', depending upon the need and after giving a fair trial to the existing one is good.

Table: 9 Time Taken for Changing Credit Policy

\begin{tabular}{|c|c|c|c|c|c|c|c|}
\hline \multirow{2}{*}{ Time Taken } & \multicolumn{6}{|c|}{ Industry Type } & \multirow{2}{*}{ Total } \\
\hline & Eng & Min & Agro & Pla & Che & Mis & \\
\hline Now and then & $\begin{array}{c}30 \\
(93.75)\end{array}$ & $\begin{array}{c}15 \\
(60.00)\end{array}$ & $\begin{array}{c}7 \\
(77.78)\end{array}$ & $\begin{array}{c}7 \\
(87.50)\end{array}$ & $\begin{array}{c}2 \\
(50.00)\end{array}$ & $\begin{array}{c}11 \\
(64.71)\end{array}$ & $\begin{array}{c}72 \\
(75.79)\end{array}$ \\
\hline Frequently & $\begin{array}{c}2 \\
(6.25)\end{array}$ & $\begin{array}{c}5 \\
(20.00)\end{array}$ & $\begin{array}{c}1 \\
(11.11)\end{array}$ & $\begin{array}{c}1 \\
(12.50)\end{array}$ & $\begin{array}{c}2 \\
(50.00)\end{array}$ & $\begin{array}{c}5 \\
(29.41)\end{array}$ & $\begin{array}{c}16 \\
(16.84)\end{array}$ \\
\hline Never & $\begin{array}{l}0 \\
-\end{array}$ & $\begin{array}{c}5 \\
(20.00)\end{array}$ & $\begin{array}{c}1 \\
(11.11)\end{array}$ & $\begin{array}{l}0 \\
-\end{array}$ & $\begin{array}{l}0 \\
-\end{array}$ & $\begin{array}{c}1 \\
(5.88)\end{array}$ & $\begin{array}{c}7 \\
(7.37)\end{array}$ \\
\hline Total & $\begin{array}{c}32 \\
(100)\end{array}$ & $\begin{array}{c}25 \\
(100)\end{array}$ & $\begin{array}{c}9 \\
(100)\end{array}$ & $\begin{array}{c}8 \\
(100)\end{array}$ & $\begin{array}{c}4 \\
(100)\end{array}$ & $\begin{array}{c}17 \\
(100)\end{array}$ & $\begin{array}{c}95 \\
(100)\end{array}$ \\
\hline
\end{tabular}

Source: Field Survey

Note: Figures in the parentheses are the percentages on the column totals. 
The Practice of allowing Cash Discounts to the Customers in the Selected Small Scale Enterprises

Discount allowed by the creditor to the debtor at the time of payment of debt is called cash discount. Cash discount is an incentive provided by the creditor to the debtor for an early or prompt payment of debt. Allowing or not allowing cash discount and the rate of discount forms part of credit policy. Thus Cash discount, which forms an important component of credit terms, induces the customers to settle the dues early. This also enables a firm to overcome the problem of cash shortage. An attempt has been made by the researcher to findout whether cash discount is allowed by select small scale enterprises or not and if so, the rate at which cash discount may be allowed by the respondent enterprises to their customers. The responses to the relevant questions, collected and presented in table 10, show that:
- As many as 75.79 per cent of the select small scale enterprises say that they do not allow any cash discount (That means the remaining 24.21 per cent of the enterprises allow cash discount to their customers), 3.16 per cent of the enterprises allow one per cent cash discount, 10.53 per cent of the enterprises allow cash discount at the rate of two per cent, 5.26 per cent of the enterprises allow cash discount at the rate of three per cent, another 3.16 per cent of the enterprises allow cash discount at the rate of four per cent, and the remaining 2.10 per cent of the enterprises allow at the rate of five per cent. Of course five is the maximum percentage of cash discount allowed. Industry-wise analysis shows that:

\section{Table: 10 The Practice of Allowing Cash Discount to the Customers in the Selected Small Scale Enterprises}

\begin{tabular}{|c|c|c|c|c|c|c|c|}
\hline \multirow{2}{*}{ Cash Discount } & \multicolumn{6}{|c|}{ Industry Type } & \multirow{2}{*}{ Total } \\
\hline & Eng & Min & Agro & Pla & Che & Mis & \\
\hline Zero percent & $\begin{array}{c}26 \\
(81.25)\end{array}$ & $\begin{array}{c}19 \\
(76.00)\end{array}$ & $\begin{array}{c}7 \\
(77.78)\end{array}$ & $\begin{array}{c}4 \\
(50.00)\end{array}$ & $\begin{array}{c}4 \\
(100)\end{array}$ & $\begin{array}{c}12 \\
(70.59)\end{array}$ & $\begin{array}{c}72 \\
(75.79)\end{array}$ \\
\hline One percent & $\begin{array}{l}0 \\
-\end{array}$ & $\begin{array}{l}0 \\
-\end{array}$ & $\begin{array}{l}0 \\
-\end{array}$ & $\begin{array}{c}1 \\
(12.50)\end{array}$ & $\begin{array}{l}0 \\
-\end{array}$ & $\begin{array}{c}2 \\
(11.76)\end{array}$ & $\begin{array}{c}3 \\
(3.16)\end{array}$ \\
\hline Two percent & $\begin{array}{c}4 \\
(12.50)\end{array}$ & $\begin{array}{c}2 \\
(8.00)\end{array}$ & $\begin{array}{c}1 \\
(11.11)\end{array}$ & $\begin{array}{c}2 \\
(25.00)\end{array}$ & $\begin{array}{l}0 \\
-\end{array}$ & $\begin{array}{c}1 \\
(5.88)\end{array}$ & $\begin{array}{c}10 \\
(10.53)\end{array}$ \\
\hline Three percent & $\begin{array}{l}0 \\
-\end{array}$ & $\begin{array}{c}2 \\
(8.00)\end{array}$ & $\begin{array}{l}0 \\
-\end{array}$ & $\begin{array}{c}1 \\
(12.50)\end{array}$ & $\begin{array}{l}0 \\
-\end{array}$ & $\begin{array}{c}2 \\
(11.76)\end{array}$ & $\begin{array}{c}5 \\
(5.26)\end{array}$ \\
\hline Four percent & $\begin{array}{c}1 \\
(3.12)\end{array}$ & $\begin{array}{c}1 \\
(4.00)\end{array}$ & $\begin{array}{c}1 \\
(11.11)\end{array}$ & $\begin{array}{l}0 \\
-\end{array}$ & $\begin{array}{l}0 \\
-\end{array}$ & $\begin{array}{l}0 \\
-\end{array}$ & $\begin{array}{c}3 \\
(3.16)\end{array}$ \\
\hline Five percent & $\begin{array}{c}1 \\
(3.13)\end{array}$ & $\begin{array}{c}1 \\
(4.00)\end{array}$ & $\begin{array}{l}0 \\
-\end{array}$ & $\begin{array}{l}0 \\
-\end{array}$ & $\begin{array}{l}0 \\
-\end{array}$ & $\begin{array}{l}0 \\
-\end{array}$ & $\begin{array}{c}2 \\
(2.10)\end{array}$ \\
\hline Total & $\begin{array}{c}32 \\
(100)\end{array}$ & $\begin{array}{c}25 \\
(100)\end{array}$ & $\begin{array}{c}9 \\
(100)\end{array}$ & $\begin{array}{c}8 \\
(100)\end{array}$ & $\begin{array}{c}4 \\
(100)\end{array}$ & $\begin{array}{c}17 \\
(100)\end{array}$ & $\begin{array}{c}95 \\
(100)\end{array}$ \\
\hline
\end{tabular}

Source: Field Survey

Note: Figures in the parentheses are the percentages on the column totals. 
- $\quad 81.25$ per cent of the engineering enterprises do not offer any cash discount and the remaining 18.75 per cent of the engineering enterprises offer two to five per cent cash discount to their customers.

- $\quad 76.00$ per cent of the mineral-based enterprises offer no discount and what so ever remaining 24.00 percent of the mineral-based enterprises, offer two to five per cent cash discount to their customers.

- $\quad 77.78$ per cent of the agro-based enterprises, do not offer any discount to their customers, but the remaining 22.22 per cent of the agrobased enterprises, offer two to four percent cash discount.

- One-half of the plastic enterprises, do not offer any cash discount to their customers, whereas the remaining one-half of the enterprises, offer one to three per cent cash discount to their customers.

- Chemical enterprises do not offer any cash discount to their customers.

- 70.59 per cent of the miscellaneous enterprises do not offer any cash discount to their customers and the remaining 29.41 per cent of the miscellaneous enterprises offer one to three per cent cash discount to their customers.
From this, it can be concluded that irrespective of the type of industry, either a majority or nearly all the select small scale enterprises do not offer any cash discount to their customers. Oral enquiry reveals that, though the small scale enterprises offer cash discount, customers have not made use of this facility, either due to ignorance or weak financial position.

\section{Method of Collection of Dues}

Collection of dues is never an easy task. Different enterprises employ different methods. The quantum of bad debts, depends upon efficacy of collection of dues, by the concerns. The small scale enterprises usually collect dues from the customers, either directly or through their representatives. Some of the enterprises may use both the methods. Table 11 shows methods of collection of dues by select small scale enterprises. As many as 45.26 per cent of the enterprises collect dues from the customers directly, 13.68 per cent of the enterprises collect dues from the customers through representatives, and the remaining 26.32 per cent of the enterprises collect dues from the customers by using both the methods. Industry-wise analysis shows that:

- $\quad 43.75$ per cent of the engineering enterprises, 40.00 per cent of the mineral-based enterprises, 22.22 per cent of the agro-based enterprises, 50.00 per cent of the plastic enterprises, 25.00 per cent of the chemical enterprises, and 70.59 per cent of the miscellaneous enterprises directly collect the dues from customers. 
Table: 11 Methods of Collection of Dues by the Selected Small Scale Enterprises

\begin{tabular}{|c|c|c|c|c|c|c|c|}
\hline \multirow{2}{*}{ Type of Action } & \multicolumn{6}{|c|}{ EnterprisesType } & \multirow{2}{*}{ Total } \\
\hline & Eng & Min & Agro & Pla & Che & Mis & \\
\hline $\begin{array}{l}\text { Direct collection from } \\
\text { the customers }\end{array}$ & $\begin{array}{c}14 \\
(43.75)\end{array}$ & $\begin{array}{c}10 \\
(40.00)\end{array}$ & $\begin{array}{c}2 \\
(22.22)\end{array}$ & $\begin{array}{c}4 \\
(50.00)\end{array}$ & $\begin{array}{c}1 \\
(25.00)\end{array}$ & $\begin{array}{c}12 \\
(70.59)\end{array}$ & $\begin{array}{c}43 \\
(45.26)\end{array}$ \\
\hline $\begin{array}{l}\text { Collection through } \\
\text { representatives }\end{array}$ & $\begin{array}{c}7 \\
(21.88)\end{array}$ & $\begin{array}{c}5 \\
(20.00)\end{array}$ & $\begin{array}{l}0 \\
-\end{array}$ & $\begin{array}{c}1 \\
(12.50)\end{array}$ & $\begin{array}{l}0 \\
-\end{array}$ & $\begin{array}{l}0 \\
-\end{array}$ & $\begin{array}{c}13 \\
(13.68)\end{array}$ \\
\hline Both & $\begin{array}{c}11 \\
(34.37)\end{array}$ & $\begin{array}{c}5 \\
(20.00)\end{array}$ & $\begin{array}{c}6 \\
(66.67)\end{array}$ & $\begin{array}{c}1 \\
(12.50)\end{array}$ & $\begin{array}{l}0 \\
-\end{array}$ & $\begin{array}{c}2 \\
(11.76)\end{array}$ & $\begin{array}{c}25 \\
(26.32)\end{array}$ \\
\hline Not applicable & $\begin{array}{l}0 \\
-\end{array}$ & $\begin{array}{c}5 \\
(20.00)\end{array}$ & $\begin{array}{c}1 \\
(11.11)\end{array}$ & $\begin{array}{c}2 \\
(25.00)\end{array}$ & $\begin{array}{c}3 \\
(75.00)\end{array}$ & $\begin{array}{c}3 \\
(17.65)\end{array}$ & $\begin{array}{c}14 \\
(14.74)\end{array}$ \\
\hline Total & $\begin{array}{c}32 \\
(100)\end{array}$ & $\begin{array}{c}25 \\
(100)\end{array}$ & $\begin{array}{c}9 \\
(100)\end{array}$ & $\begin{array}{c}8 \\
(100)\end{array}$ & $\begin{array}{c}4 \\
(100)\end{array}$ & $\begin{array}{c}17 \\
(100)\end{array}$ & $\begin{array}{c}95 \\
(100)\end{array}$ \\
\hline
\end{tabular}

Source: Field Survey

Note: Figures in the parentheses are the percentages on the column totals.

- 21.88 per cent of the engineering enterprises, 20.00 per cent of the mineral-based enterprises, and 12.50 per cent of the plastic enterprises collect dues through their representatives.

- $\quad 34.37$ per cent of the engineering enterprises, 20.00 per cent of the mineral-based enterprises, 66.67 per cent of the agro-based enterprises, 12.50 per cent of the plastic enterprises and 11.76 per cent of the miscellaneous enterprises use both these methods.

From this, it can be deduced that though both the methods - direct collection and collection through representatives - are used by the selected small scale enterprises, 'direct collection from the customers' method appears to more popular than the second method.

\section{Realization of Overdue Accounts}

Table 12 shows the time taken to realize the overdue accounts. As per the table, 37.89 per cent of select small scale enterprises say that they can collect overdue accounts within one month, another 37.89 per cent of the enterprises are able to collect within two months, and 9.47 per cent of the enterprises take more than two months, to collect overdue accounts. Industry-wise analysis shows that: 
Table: 12 Time Taken to Collect Overdue Accounts

\begin{tabular}{|c|c|c|c|c|c|c|c|}
\hline \multirow{2}{*}{ Time Taken } & \multicolumn{6}{|c|}{ Industry Type } & \multirow{2}{*}{ Total } \\
\hline & Eng & Min & Agro & Pla & Che & Mis & \\
\hline Within one month & $\begin{array}{c}12 \\
(37.50)\end{array}$ & $\begin{array}{c}10 \\
(40.00)\end{array}$ & $\begin{array}{c}01 \\
(11.11)\end{array}$ & $\begin{array}{c}02 \\
(25.00)\end{array}$ & $\begin{array}{c}01 \\
(25.00)\end{array}$ & $\begin{array}{c}10 \\
(58.82)\end{array}$ & $\begin{array}{c}36 \\
(37.89)\end{array}$ \\
\hline Within two months & $\begin{array}{c}14 \\
(43.75)\end{array}$ & $\begin{array}{c}09 \\
(36.00)\end{array}$ & $\begin{array}{c}05 \\
(55.56)\end{array}$ & $\begin{array}{c}02 \\
(25.00)\end{array}$ & $\begin{array}{l}0 \\
-\end{array}$ & $\begin{array}{c}06 \\
(35.29)\end{array}$ & $\begin{array}{c}36 \\
(37.89)\end{array}$ \\
\hline More than two months & $\begin{array}{c}06 \\
(18.75)\end{array}$ & $\begin{array}{c}01 \\
(4.00)\end{array}$ & $\begin{array}{c}02 \\
(22.22)\end{array}$ & $\begin{array}{l}0 \\
-\end{array}$ & 0 & $\begin{array}{l}0 \\
-\end{array}$ & $\begin{array}{c}09 \\
(9.47)\end{array}$ \\
\hline Not applicable & $\begin{array}{l}0 \\
-\end{array}$ & $\begin{array}{c}05 \\
(20.00)\end{array}$ & $\begin{array}{c}01 \\
(11.11)\end{array}$ & $\begin{array}{c}04 \\
(50.00)\end{array}$ & $\begin{array}{c}03 \\
(75.00)\end{array}$ & $\begin{array}{c}01 \\
(5.88)\end{array}$ & $\begin{array}{c}14 \\
(14.74)\end{array}$ \\
\hline Total & $\begin{array}{c}32 \\
(100)\end{array}$ & $\begin{array}{c}25 \\
(100)\end{array}$ & $\begin{array}{c}9 \\
(100)\end{array}$ & $\begin{array}{c}08 \\
(100)\end{array}$ & $\begin{array}{c}04 \\
(100)\end{array}$ & $\begin{array}{c}17 \\
(100)\end{array}$ & $\begin{array}{c}95 \\
(100)\end{array}$ \\
\hline
\end{tabular}

Source: Field Survey

Note: Figures in the parentheses are the percentages on the column totals.

- $\quad 37.50$ per cent of the engineering enterprises, 40.00 per cent of the mineral-based enterprises, 11.11 per cent of the agro-based enterprises, 25.00 per cent of the plastic enterprises, and 58.82 per cent of the miscellaneous enterprises say that they collect overdue accounts within one month period.

- 43.75 per cent of the engineering enterprises, 36.00 per cent of the mineral-based enterprises, 55.56 per cent of the agro-based enterprises, 25.00 per cent of the plastic enterprises, and 35.29 per cent of the miscellaneous enterprises are able to collect overdue accounts within two months.

- $\quad 18.75$ per cent of the engineering enterprises, 4.00 per cent of the mineral-based enterprises, and 22.22 per cent of the agro-based enterprises take more than two months time to collect overdue accounts.

- For 20.00 per cent of the mineral-based enterprises, 11.11 per cent of the agro-based enterprises, 50.00 per cent of the plastic enterprises, 75.00 per cent of the chemical enterprises, and 5.88 per cent of the miscellaneous enterprises it is not applicable.

From the above, it may concluded that a majority of the select small scale enterprises (75.78 per cent of the enterprises) are able to collect overdue accounts as well within two months.

\section{Action Taken Against Defaulters}

Whatever may be the care taken in assessing the creditworthiness of the customer and there are bound to be care taken in collecting the debts, defaulters When customers do not honour their obligations, an enterprise cannot afford to spare them. Appropriate action has to be taken to collect the debts. If all other efforts fail the only way is to proceed against the defaulter legally and file a suit in the appropriate court of law, in order to seek justice. But going to the court of law, is a time consuming alternative act. Legal cases take a lot of time to be settled. Justice delayed is justice denied. 
That is why some people do not prefer to go to the court of law. Any how it has been desired to find out the action taken by the select small scale enterprises, against defaulting customers. Table 13 shows the action taken by the select small scale enterprises against defaulting customers. According to the table, only 3.16 per cent of the select small scale enterprises 'always go to the court of law', 47.37 per cent of the enterprises 'sometimes go to the court of law', and the remaining 49.47 per cent of the enterprises 'never go to court of law'. Industry-wise analysis shows that:

- $\quad 3.13$ per cent of the engineering enterprises and 8.00 per cent of the mineral-based enterprises only prefer 'always to go to court of law.
- $\quad 53.12$ per cent of the engineering enterprises, 60.00 per cent of the mineral-based enterprises, 11.11 per cent of the agro-based enterprises, 12.50 per cent of the plastic enterprises, 75.00 per cent of the chemical enterprises, and 47.06 per cent of the miscellaneous enterprises 'sometimes prefer to go to the court of law' in case of any default.

- $\quad 43.75$ per cent of the engineering enterprises, 32.00 per cent of the mineral-based enterprises, 88.89 per cent of the agro-based enterprises, 25.00 per cent of the chemical enterprises, and 52.94 per cent of the miscellaneous enterprises 'never prefer to go to the court of law'.

Table: 13 Action Taken Against Default Customers

\begin{tabular}{|c|c|c|c|c|c|c|c|}
\hline \multirow{2}{*}{ ActionTaken } & \multicolumn{6}{|c|}{ Industry Type } & \multirow{2}{*}{ Total } \\
\hline & Eng & Min & Agro & Pla & Che & Mis & \\
\hline $\begin{array}{l}\text { Always go to } \\
\text { court of law }\end{array}$ & $\begin{array}{c}1 \\
(3.13)\end{array}$ & $\begin{array}{c}2 \\
(8.00)\end{array}$ & $\begin{array}{l}0 \\
-\end{array}$ & $\begin{array}{l}0 \\
-\end{array}$ & $\begin{array}{l}0 \\
-\end{array}$ & $\begin{array}{l}0 \\
-\end{array}$ & $\begin{array}{c}3 \\
(3.16)\end{array}$ \\
\hline $\begin{array}{l}\text { Sometimes go to } \\
\text { court of law }\end{array}$ & $\begin{array}{c}17 \\
(53.12)\end{array}$ & $\begin{array}{c}15 \\
(60.00)\end{array}$ & $\begin{array}{c}1 \\
(11.11)\end{array}$ & $\begin{array}{c}1 \\
(12.50)\end{array}$ & $\begin{array}{c}3 \\
(75.00)\end{array}$ & $\begin{array}{c}8 \\
(47.06)\end{array}$ & $\begin{array}{c}45 \\
(47.37)\end{array}$ \\
\hline $\begin{array}{l}\text { Never go to } \\
\text { court of law }\end{array}$ & $\begin{array}{c}14 \\
(43.75)\end{array}$ & $\begin{array}{c}8 \\
(32.00)\end{array}$ & $\begin{array}{c}8 \\
(88.89)\end{array}$ & $\begin{array}{c}7 \\
(87.50)\end{array}$ & $\begin{array}{c}1 \\
(25.00)\end{array}$ & $\begin{array}{c}9 \\
(52.94)\end{array}$ & $\begin{array}{c}47 \\
(49.47)\end{array}$ \\
\hline Total & $\begin{array}{c}32 \\
(100)\end{array}$ & $\begin{array}{c}25 \\
(100.00)\end{array}$ & $\begin{array}{c}9 \\
(100)\end{array}$ & $\begin{array}{c}8 \\
(100.00)\end{array}$ & $\begin{array}{c}4 \\
(100)\end{array}$ & $\begin{array}{c}17 \\
(100)\end{array}$ & $\begin{array}{c}95 \\
(100)\end{array}$ \\
\hline
\end{tabular}

Source: Field Survey

Note: Figures in the parentheses are the percentages on the column totals.

From the above analysis it may be concluded that a majority of the select small scale enterprises, either do not prefer to go to the court of law or sometimes opt to go to the court of law in case of default of any customer.

\section{Suggestions}

> 'Money lenders', 'friends and relatives', 'trade creditors' and 'deposits from customers' are traditional and unorganized sources of finance. It is not advisable to depend upon unorganized sources of finance. 
$>$ Small enterprise and individual credit rating should be taken up by an independent organization in the country, just like in some developed countries, to facilitate getting and granting of credit to customers.

$>$ Different ratios relating to debtors, debtors' turnover ratio and debtors collection period should be calculated and studied by the management of the small scale enterprises for the purpose of improving receivables management.

$>\quad$ Late payment is a perpetual problem for small firms. The usual natural reaction of small businesses suffering from late payments from their customers, is to delay payment to creditors. However, paying bills late (unauthorised credit) is the most expensive form of business finance. Yet, the majority of small business owner/managers are unaware of the opportunity costs of trade discounts forgone, when delaying payments to suppliers.

> In the small scale enterprises, where the sole proprietors/partners/promoters have no knowledge about receivables management techniques, they may hire the services of trained persons to look after the units' financial aspects, more specifically management of working capital. Otherwise, the owners of the small scale enterprises themselves may be trained in the basics of working capital management. Programmes like Entrepreneurial Development Programmes may be conducted by DICs and Financial Institutions.

\section{Conclusion}

A large number of the select small scale enterprises provide credit as a motivating force for effective sales. 'Debtors/Bills Receivables' is a significant form of credit sales and the duration of credit period in the small scale enterprises is generally one to two months.
Many select small scale enterprises have developed their credit policy independent of their competitors while a few refer to their competitors' credit policy. A majority of the select small scale enterprises modify their credit policy now and then. The credit worthiness of the customers is judged based upon their past association with the enterprise. The select small scale enterprises, though offer cash discount; customers generally do not make use of this facility. Most of the enterprises do not prefer to go to the court of law. A few enterprises go to court of law against the default customers. A majority of the mineral, plastic and miscellaneous enterprises collect overdue accounts within one month.

There is scope for improvement in the receivables management practices of small scale enterprises, which in the long run, will save money and time. Better credit management planning could also facilitate the higher utilization of trade discounts which can save large amounts of money.

\section{References:}

1. Advisory Council on Science and Technology, (ACOST) (1990), The Enterprise Challenge:Overcoming Barriers to Growth in small Firms, HMSO, London.

2. Asim Kumar Das, Nilkhil Bhusan Dey, (2004) "Effective Management of Receivables in Small Business", SEDME, Vol.31, No.1, pp18-25.

3. Aston Business School, (1991), Constraints on the Growth of Small Firms, Department of Tradeand Industry, HMSO, London.

4. Bolton J.E. (1971), 'Small Firms, Report of the Committee of Inquiry on Small Firms', HMSO, London, Cmnd. 4811.

5. Cambridge Small Business Research Centre (CSBRC), (1992), The State of British Enterprise, University of Cambridge.

6. CIMA (1994), 'CIMA to Investigate Trade Credit Management', CIMA Research Foundation Newsletter, Vol. 4(11), p.1. 
7. Mallikarjunappa.T, (1991) "Inventory and Receivables Position of Small Scale Units: A Case Study", SEDME, Vol.XVIII, No.2, pp.43-53.

8. Michaelas, N. Chittenden, F. and Poutziouris, P., 'Financial Policy and Capital Structure Choice in UK SMEs: Evidence From Company
Panel Data', Small Business Economics, Vol. 12, No. 2, 1999, pp. 113-130

9. Peel, M.J., and Wilson, N. (1996), 'Working Capital and financial Management Practices in the Small Firms Sector', International Small Business Journal, Vol. 14(2), July-March, pp. 52-68. 